\title{
Qualified Person Investigational Product Certification Document
}

National Cancer Institute

\section{Source}

National Cancer Institute. Qualified Person Investigational Product Certification

Document. NCI Thesaurus. Code C115720.

Records from a qualified person that confirm that an investigational product has been manufactured according to Good Manufacturing Processes (GMP). 